JURNAL SENI MUSIK

\title{
THE EXISTENCE OF AL-MADARIS TERBANGAN MUSIC IN PLADEN VILLAGE, JEKULO DISTRICT, KUDUS REGENCY
}

\author{
Panji Wahyu Mukti \\ Fakultas Bahasa dan Seni, Universitas Negeri Semarang, Indonesia \\ Syahrul Syah Sinaga ${ }^{\bowtie}$ \\ Fakultas Bahasa dan Seni, Universitas Negeri Semarang, Indonesia
}

\begin{tabular}{|c|c|}
\hline Article Info & Abstract \\
\hline \multicolumn{2}{|l|}{ Submitted : April, 2021} \\
\hline Revised : May, 2021 & The existence of Al-Madais' terbangan music group in Pladen Village cannot be separated \\
\hline Accepted : May, 2021 & $\begin{array}{l}\text { from the motivation of its members to preserve the terbangan music as a means of da'wah and } \\
\text { worship. Despite the limited time, facilities, and infrastructure as well as knowledge and skills, the } \\
\text { group still strives to preserve Islamic culture amid the fast growth of the modern era. Therefore, the }\end{array}$ \\
\hline $\begin{array}{l}\text { Keywords: } \\
\text { Existence, terbangan music, } \\
\text { Al-Madais, da'wah }\end{array}$ & $\begin{array}{l}\text { purpose of this study is to describe the existence of Al-Madais' terbangan music arts. This study } \\
\text { uses a qualitative descriptive method, with data collection techniques through observation, } \\
\text { interviews, and documentation. Meanwhile, the data analysis technique was carried out by } \\
\text { reducing, presenting, and verifying data. The results of the study indicate that the existence of the }\end{array}$ \\
\hline & $\begin{array}{l}\text { Al-Madais terbangan music group, in terms of the adopted strategy, one of which is good } \\
\text { management. Then in terms of consistency, it is carried out with the existence of an organizational } \\
\text { structure, regeneration process, and mundane rehearsal. The innovation is carried out by } \\
\text { imagination and creativity without leaving its cohesiveness and characteristics. The } \\
\text { acknowledgment of the Al-Madais existence is proved by performing at various events and support } \\
\text { from the government. }\end{array}$ \\
\hline
\end{tabular}




\section{Panji Wahyu Mukti/JURNAL SENI MUSIK (10) (1)}

\section{INTRODUCTIONS}

Indonesia has a variety of traditional arts. The diversity of traditional art of Indonesia growth in regions and it has certain characteristics. The thing that causes this diversity to occur is because the customs in each region are different, including the diversity of arts that are owned and rich in artistic treasures (Prier, 1991:74).

Sinaga (2006:1) stated that traditional art is an art form that is sourced and rooted and has been felt and owned by the community in its circle. The life and processing of traditional arts are based on the taste of the supporting community, including the view of life, the value of traditional life, ethics, aesthetic sense, as well as expressions of environmental culture which are then passed on to future generations. The existence of traditional arts can be interpreted that traditional arts exist. This opinion means being present and living in the community according to their needs. The existence of traditional arts is determined by the environment that builds the art.

Traditional art cannot be separated from the life of its supporting community. Traditional art lives and develops by the development of society (Herawati, 2017: 449). Various communities are supporting and preserving traditional arts in Indonesia as a result of the influence of Islamic cultures such as gambus, tanjidor, kasidah, zamroh, terbangan, and others. The existence of diverse ethnicities and communities is what makes traditional art has its own characteristics and has its own aesthetic value. The art of terbangan that is present amid the supporting community and its conservationists also has its uniqueness and aesthetics, such as the intersection of eastern and western cultur as well as local traditions, lead to acculturation (Sinaga, 2006: 2).

Al-Madais terbangan music group in Pladen Village is one of the many traditional arts in Kudus that has a different characteristics and styles. This group has been formed for a long time and can survive until now and is still aspired by public. It is undeniable that this group has developed from the beginning of its formation until now. This is an effort to maintain the existence of terbangan music so that it still exists and fulfill the public demand. Sumaryono (2011: 31) stated that art which is align with local customs and is useful for social interests, will remain exsiy and sustainable.
Hadi (2012:35) mentioned that the existence of an art in society, because of the relationship between artists as an integrated system that determines the success of a performance. Thus, the art of terbangan also has a role to strengthen relations between members of the community. There is a sense of togetherness between fellow members of the art conservation group and the supporting community. The existence of the terbangan music in Pladen Village cannot be separated from the motivation of the members who still want to preserve the art in their village. This is based on the fact that terbangan is not only used as entertainment, but also as a means of worship. In other words, it indirectly invited fellow people to read sholawat (pray) through terbangan music.

The terbangan music art group in Pladen village became the target of research because they have a high motivation to maintain their ancestor's inheritance. This terbangan music art group itself is also able to survive along with the emergence of new types of music and is in great demand by the public. Therefore, this terbangan music group always tries to cadre so that the art of terbangan music is maintained. Despite the limited time, facilities, and infrastructure as well as limited knowledge and skills, the Al-Madais Terbangan music art group in Pladen Village is still trying to preserve this Islamic culture amid today's modern times.

\section{METHODS}

The method used in this study is descriptive qualitative. This qualitative descriptive research is aimed at describing and explaining existing phenomena, both natural and human-engineered, which pays attention to the characteristics, quality, and interrelationships between activities (Sukmadinata, 2016:74). The research location is in Pladen Village, Jekulo District, Kudus Regency. The object to be studied in this study is the Al-Madais terbangan music group.

The research targets are coaches, trainers, and members of the Al-Madais terbangan music group, as well as local village community leaders. Data collection techniques were carried out in three stages, observation, interviews, and documentation. The data validity technique used triangulation methods, which is comparing data from interviews with observations of informants. In data analysis techniques, researchers used three flow of activities that must be carried out, data reduction, data presentation, and conclusions 
(Sugiyono, 2013:337) in the study of Al Madais' terbangan music art existence in Pladen Village, Jekulo, Kudus.

\section{RESULTS AND DISCUSSION}

The existence of art that has received recognition needs to be preserved and developed to maintain the unity of the existence of the art (Farhani, 2016: 11). Regarding the existence of the terbangan music group, the group itself is considered exist when it fulfills several requirements including a strategy. Strategies are needed to compile various activities that support that the existence of the group is worth. The music group must be consistent, which means they have to maintain the quality and the characteristics of the music group. It is usually manifested in performing on various events with interesting idea, innovation, and highlighting the characteristics of the music group itself. The music group that is considered exist must also go through the recognition process. The recognition came from the public and the government (Hadi, 2014: 14).

The existence of Al-Madais's terbangan art group in the village of Pladen Jekulo Kudus can be seen in terms of strategies, consistency, innovation, and community recognition. The strategy is taken to preserve traditional art, one of which is good management. Management inferentially concerned with cooperation among people to regulate everything to achieve goals so that the application depends on the expected goal. The management of AL-Madais terbangan music arts groups are based on experience, for example, when they were about to perform, everything is planned, discussed, and evaluated. However, when viewed from activities to prepare everything in performance, the preparations about the songs lists, used costumes, completeness of musical instruments and so on, Al-Madiss's actually has implemented a good management. Then to carry out what has been planned, it needs to be well organized so that there is no overlap in the preparation of the performance, that leads to the failure. Therefore, the organization is the division of duties and responsibilities to people who are by the ability.

In carrying out the process of organizing, the group did it through several series of activities included the separation of duties and responsibilities, classification of activities according to their functions, and the provision of equipment. The music player of the groups consisted of 2 vocalists with voice 1 and voice 2 , then people who played musical instruments such as 4 people, jedur player 1 person, darbuka player 1 person and 2 players of kenting and 1 tambourin palyer. The total average plyers in a performance are 25 people. Members who did not get a task as a vocal and plays musical instruments, became backing vocal. Thus, the application of professional management is a form of strategy to help the continuity of the music group itself because with the implementation of good management will be created cooperation in regulating everything to achieve the expected goals.

\section{Conceptual Consistency}

The existence of Al-Madais terbangan music art for the Pladen Village community is a manifestation of a social commitment. Psychologically, their awareness to carry out the mandate of their ancestors to liven up their traditional arts is the basis of their commitment and consistency in their arts. In this case, the existence of an organizational structure, regeneration process, and mundane training play an important role in maintaining the consistency of the existence of the group in Pladen Jekulo Kudus Village. The existence of a management is very important for the consistency of the group activities. This is done so that in carrying out one activity with other activities it becomes more focused and does not clash with each other. In addition, the existence of management makes the division of tasks balanced and objective. Assignment of tasks according to the roles and abilities of members. To maintain the consistency and presence of management in the group, it is necessary to have a regeneration process to maintain the completeness of personnel.

The regeneration process is one of the most important things to maintain the consistency and sustainability of the arts group. The regeneration of new members in the AlMadais group is carried out by inviting children from an early age to read shalawat and practice together. It aims to foster the spirit of children and adolescents to have a soul or a sense of love for religion through shalawat and later they are interested in joining as one of the personnel of the Al-Madais terbangan musi group.

The Al-Madais terbangan music group also routinely performs exercises as do other art groups. Exercise is an activity that is carried out repeatedly to improve and achieve certain goals, both individually and in groups. In addition, training is also an effort to increase cohesiveness and intimacy in presenting shlawat music. 
Innovation in preserving traditional arts requires the solidarity of the players to achieve the goal. Solidarity is a sense of togetherness, a sense of one interest, a sense of sympathy, as a member of the Al-Madais group. Therefore, it is very important to build a sense of solidarity between members of the Al-Madais music group in Pladen Village. With solidarity, the Al-Madais music group can be united in realizing a common goal. In terms of playing music, AlMadais also needs cohesiveness, because there are several musical instruments being played, so solid cooperation between members is needed. Therefore, the Al-Madais music group is very concerned about an arrangement, technique, harmonization of instruments, and the cohesiveness of the players.

Furthermore, the performers of AlMadais music also continue to strive to develop and innovate. This is to attract people's interest but still with its characteristics. As for the characteristics of the Al-Madais music group, namely (1) the use of musical instruments consisting of "flying papat", plus darbuka, jedur, and tambourines, (2) the songs are played rhythmically "shalawat" from the middle east," shalawat" java, "shalawat" compilation, (3) the vocalists both vocalist 1 and vocalist 2 and are in a sitting position and do not make dynamic movements, (4) there are two versions of the technique of playing musical instruments, banjari and habsyi. The source of the poems sung by the musical arts of Al-Madais in practice comes from the book of Qosidah Islamiyah, which focuses on Islamic-themed poems written by Misbahul Munir and the book of 1000 Evergreen Qosidah which is a collection of shalawat texts on the rebana banjari, written by H. Abdullah Zaini D Asnawi. The poems presented are usually also adapted to the needs of the event.

The Al-Madais terbangan music group in Pladen Village does not innovate excessively in the terbangan art they work on, with the phenomenon of modernization that is in accordance with the tastes of modern society, they assume that maintaining terbangan art in accordance with the initial tradition will still maintain the cultural values of art. itself. By maintaining the basic values of traditional art, this traditional art is preserved and becomes its main characteristic.

\section{Community Recognition}

The music of Al-Madais is acknowledged by the public. This is evident from the offers to perform at various events or celebrations. In addition, the enthusiasm of the community is huge in each of their performances. They enjoyed the show and persisted until the end of the show. Then because of the frequent intensity of the performances, this music group exist in various ways, one example is to produce an increase in the quality of their music. With that, the Al-Madais terbangan music group exists. The community provides support through invitations for performances to members of the musical arts of Al-Madais when there are community members who have special celebrations. Usually, the community invites members of the Al-Madais musical arts when members of the community have special celebrations such as aqiqah, circumcision, selapanan, weddings or recitation. The community invites members of the Al-Madais musical group in addition to preserving traditional arts, as well as a form of gratitude to Allah SWT for having been given sustenance and happiness in all affairs.

In the performance, the Al-Madais group performed songs containing the life advice and blessings of the Prophet. The songs that are usually presented are prayers from the Middle East, Javanese prayers, compilations of prayers (self-arranged music) such as the song Qomarun Sidnan Nabi. There are 2 versions of the terbangan playing technique used, namely Banjari and Habsyi.

Furthermore, another important thing is the support of the village government in efforts to preserve the art of Al-Madais "flying" music in Pladen Village. Based on the results of interviews with village officials, they confirmed this. In general, the local village government is very supportive and hopes that all arts in the village can develop rapidly. The arts in the area can be used as a unifying tool for the community. The village government strongly supports various existing arts with a record that the arts are accepted in the community and do not conflict with the culture and customs that apply in the community. The Pladen Village Government has one program related to various arts in the village trying to preserve the existing arts, as well as excavating the hidden arts.

The plan carried out by the Pladen Village Government in relation to the preservation of Al-Madais terbangan musical arts in the area is by holding a public recitation while inviting the Al-Madais terbangan musical arts group to perform. Recitation is held every August to celebrate Indonesian Independence 


\section{Panji Wahyu Mukti/JURNAL SENI MUSIK (10) (1)}

Day. In the future, people hope that the AlMadais music group will still exist and be accepted by the community. Also, this art can be used as a medium of da'wah, because preaching through music with the beauty of the syair (lyrics) can attract people's empathy. They accept the syair as a symbol and as a realization of the da'wah message.

\section{CONCLUSION}

Al-Madaris terbangan music art was formed in 1990. Since the beginning, the musical instruments used by the group were pure terbang papat without adding other musical instruments. Nevertheless, along with its development, there are additional tools in the form of kenting and tifa. The reason for the addition of these tools in this terbangan group is intentional according to the needs so that this art can still exist. Regarding the existence of the Al-Madais terbangan music group in Pladen Jekulo Kudus Village, it is seen from the perspective of strategy, consistency, innovation, and community recognition.

The strategy taken to preserve the art of AlMadais' terbangan music is good management. Then in terms of consistency, it is carried out with the existence of an organizational structure, regeneration process, and routine training. The innovation is carried out by imagination and creativity without leaving its cohesiveness and characteristics. Then the public's acknowledgment of the existence of the Al-Madais music group is evident from the experience of performing at various celebrations and supports from the local village government.

\section{REFERENCES}

Farhani, Atiyatul. 2016. Eksistensi Pertunjukan Kesenian Rebana Hadrah Darul Ma'rifah di Warung Buncit. Semarang: Universitas Negeri Semarang.

Hadi, Y. Sumandiyo. 2012. Seni Pertunjukan dan Masyarakat Penonton. Yogyakarta: BP ISI Yogyakarta.

Herawati, Ika Prawita. 2017. Eksistensi Kesenian Jepin di Dusun Bandungan Desa Darmayasa Kecamatan Pejawaran Kabupaten Banjarnegara.

Prier, Karl Edmund. 1991. Sejarah Musik Jilid I. Yogyakarta: Pusat Musik Liturgi.

Sinaga, Syahrul Syah. 2006. Fungsi dan Ciri Khas Kesenian Rebana di Pantura Jawa Tengah. Harmonia Jurnal Pengetahuan dan Pemikiran Seni.

Sugiyono. 2013. Metode Penelitian Kualitatif Kuantitatif dan R\&D. Bandung: Alfabeta.

Sukmadinata, Nana Syaodih. 2013. Metode Penelitian Pendidikan. Bandung: PT. Remaja Rosdakarya.

Sumaryono. 2011. Antropologi Tari dalam perspektif Indonesia. Yogyakarta: Badan Penerbit ISI 